\title{
Üniversite Öğrencilerinin Girişimci Kişilik Özelliklerinin Değerlendirilmesi: Yalova Meslek Yüksekokulu Öğrencilerine Yönelik Bir Uygulama
}

\author{
Yrd.Doç.Dr. Duygu TALİH AKKAYA* \\ Yrd.Doç.Dr. Emel YILDIZ ${ }^{* *}$ \\ Yrd.Doç.Dr. Yasemin KOLDERE AKIN ${ }^{* * *}$
}

\section{Özet}

Özellikle son yıllarda küreselleşmeyle birlikte yoğun rekabet ortamının yaygınlaşması girişimcilik kavramının önemini daha da arttırmıştır. Sanayi toplumundan bilgi toplumuna geçişte önemi giderek artan girişimcilik, ekonomik kalkınma ve istihdam yaratmanın temel faktörlerinden biri haline gelmiştir. Girişimcilik potansiyeli birçok faktörden etkilenmektedir. Bu faktörlerden biri de kişilik özellikleridir.

Çalışmanın temel amacı, gelecekte girişimci olmayı planlayan üniversite öğrencileri ile planlamayanlar arasında kişilik özellikleri bakımından fark olup olmadığını belirlemektir. Bu amaçtan yola çıkarak girişimci ve girişimcilik kavramları ile girişimci kişilik özellikleri üzerinde durulmuş, ardından anket yöntemiyle bu özelliklerin potansiyel girişimciler olan üniversite öğrencilerinin girişimcilik eğilimine etkisi incelenmiş ve elde edilen veriler analiz edilerek değerlendirilmiştir.

Anahtar Kelimeler: Girişimcilik, Kişilik Özellikleri, Üniversite Öğrencileri

Evaluation Of Entrepreneurial Personality Characteristics Of University Students: An Application Of Yalova Vocational School Students

\section{Abstract}

Especially in recent years, both globalization and proliferation of intense competition environment raised the importance of entrepreneurship concept. Entrepreneurship, importance of which has gradually increased during the transition from industrial society to information society, has become one of the basic factors on economic development and employment creation. The potential of entrepreneurship is affected by numerous factors. One of these factors is personality traits.

\footnotetext{
* Yalova Üniversitesi Yalova Meslek Yüksekokulu, duygutalih@gmail.com

** Trakya Üniversitesi İktisadi ve İdari Bilimler Fakültesi, yildizn@hotmail.com

*** Trakya Üniversitesi İktisadi ve İdari Bilimler Fakültesi, yaseminkoldere@trakya.edu.tr
} 
The main purpose of this study is to determine whether there is a difference in terms of personality characteristics, between the students who plan to be an entrepreneur and who don't plan to be an entrepreneur. Starting from this purpose, entrepreneur and entrepreneurship concepts and personality traits of an entrepreneur are emphasized, then effect of these personality traits on entrepreneurship tendency of university students who are potential entrepreneurs, is investigated by means of survey method and finally obtained data is evaluated by analysing.

Keywords: Entrepreneurship, Personality Traits, University Students

\section{GíRIŞ}

Geçtiğimiz yüzyılın başlarına kadar girişimcilik kişilerin kendi sermayeleri ile iş kurması olarak algılanmaktayken, yaşanan baş döndürücü gelişmelerle birlikte girişimci insan tipi bambaşka nitelikler kazanmaya başlamış ve bu niteliksel değişim aynı zamanda girişimcinin ekonomik değerini ve dolay1sıyla toplumdaki önemini de arttırmıştır. Nitekim bu gelişmelerin bir sonucu olarak genel ekonomide girişimcilik bir üretim faktörü olarak kabul edilmeye başlanmıştır (Ören \& Biçkes, 2011, 70).

Girişimcilik ve girişimci terimlerinin ifade ettiği anlamlar, akademik çevreler ve uygulayıcılar arasında farklılık göstermektedir. Buna rağmen Girişimcilik Merkezlerinde girişimcilik, genel olarak yenilikçi ürünler, hizmetler ve teknolojik süreçler ortaya koyma vasıtasıyla topluma katkı sağlama imkânı sunan çekici bir kariyer olarak görülmektedir (Zarafshani \& Rajabi, 2011, 631).

Tipik olarak girişimci, bir fırsatı keşfeder ve kaynakları bir araya getirip bu faktörleri pazara bazı yenilikler sunacak şekilde yatırım için organize eder. Girişimciler aslında refah yaratımı ve değişim için birer araç gibi hareket etmektedirler (Arasteh, Enayati, Zameni, \& Khademloo, 2012, 5736).

Girişimciliği teşvik etmek dünya genelinde hükümetler tarafindan ulusal bir öncelik olarak görülmektedir. Hükümetlerin bu ilgisi, küçük işletmelerin ekonomi açısından çok fazla sayıda iş olanağı yaratması, yenilikçiliğin önemli bir kaynağını temsil etmesi, ulusal üretkenliği artırması ve fakirliği azaltmasindan kaynaklanmaktadır (Fairlie \& Holleran, 2012, 366).

Çok sayıda Avrupa ülkesinde, işsizlere iş kurmaları için finansal ve diğer türden destek sağlama programları mevcuttur ve Amerika Birleşik Devletlerinde çeşitli eyaletlerde, insanların işsizlik sigortalarını bırakmaları amacıyla kendi işinde çalışmayı teşvik eden programlar bulunmaktadır (Fairlie \& Holleran, 2012, 366-367).

Girişimciliğin yeniliklerin ortaya çıkması, yeni istihdam alanları yaratılması, yeni sektörler ve işletmeler kurulması, ekonomik büyümenin ve toplumun refah seviyesinin artması bakımından ekonomik ve sosyal hayatta önemli bir rolü vardır (Dündar \& Ağca, 2007, 122). 
Üniversiteler, girişimci potansiyeli ve yetenekleri geliştirmenin öneminin farkında olmalı, öğrencileri girişimci yeteneklerle nasıl donatacağına odaklanmalı, istihdamın alternatif bir yolunun daha olduğuna dair farkındalık yaratmalı ve yeteneklerin transfer edilebilir olduğu hususunu göz ard1 etmemelidir (Zarafshani\& Rajabi, 2011, 630).

\section{Girişimci ve Girişimcilik}

Girişimcilik kavramı, köken itibariyle Fransız Cantillon'un kullandığ1 ve girişimci anlamına gelen "entreprendre" terimine dayanmaktadır. 1755' de Fransız Cantillon bu terimi, ekonomik parametreler içerisinde, kazanç elde etmeyi ve belirsizliği göğüslemeye arzulu, önsezi (basiret) ve yaratma yeteneği olan bir bireyi tanımlamak için kullanmıştır. Girişimcilik kavramı, literatürde pek çok yazar tarafindan farklı boyutları vurgulanarak tanımlanmaya çalışılmıştır. Kavramla ilgili yapılan bütün tanımlamalarda ortak nokta girişimciliğin çeşitli fırsatların değerlendirildiği bir süreç olarak ele alındığıdır (Dündar \& A ğca, 2007, 124).

Klasik anlamda girişimci, daha çok kendi işini kuran, çeşitli üretim faktörlerini bir araya getirerek ve risk üstlenerek üretim sürecinde bulunan ve bunun sonucunda da kar elde etmeyi amaçlayan kişi olarak tanımlanmaktadır. Günümüzde ise girişimci; sürekli olarak mevcut durumun ötesine geçebilmek amacıyla üretkenlik yeteneğini kullanarak daha önce hiçbir kimse tarafından fark edilememiş firsatları tespit edip kullanabilen kişi şeklinde algılanmakta ve bu anlamda girişimciye değişimin temsilcisi olarak bakılmaktadır (Ören \& Biçkes, 2011, 71).

Girişimciler genellikle yapmaya başladıkları şeyde ısrarcı davranan, saatlerce çalışmak hususunda istekli olan, standartlara uymayan, kavramları kapsamlı şekilde inceleyen ve kendi kişisel sezgilerine uygun şekilde hareket eden insanlar olarak tanımlanır (Yıldız, 2012, 83).

Yapılan açıklamalar doğrultusunda; günümüzde girişimci kavramıyla ifade edilmek istenenin işletme sahibi olsun ya da olmasın, herhangi bir işyerinde fiilen çalışsın ya da çalışmasın, kısaca bulunduğu herhangi bir ortamda ya da üstlendiği herhangi bir rolde mevcut durumun işleyişini olumlu anlamda farklılaştıran bireyler olduğu söylenebilir (Ören \& Biçkes, 2011, 71).

Son yapılan araştırmanın bir sonucu da gelişmekte olan ülkelerdeki girişimcilik algısının, gelişmiş ülkelerdeki girişimcilik algısından farklı olduğudur ve bu farklılıklarının idrak edilmesi global ekonomi ve yüksek öğrenim açısından kritik öneme sahiptir. Örneğin, Davey ve diğerlerinin araştırma sonucu, gelişmekte olan ekonomilerden gelen öğrenciler, endüstrileşmiş Avrupalı emsallerine göre, gelecekteki kariyerlerini birer girişimci olarak hayal 
etmelerinin ve girişimciliğe karşı daha pozitif yaklaşmalarının daha muhtemel olduğunu işaret etmektedir (Arasteh ve diğerleri, 2012, 5737).

\section{Girişimci Kişilik Özellikleri}

Rekabetin küresel bir nitelik kazandığı, ekonomiler üzerinde ulusal düzenlemelerin etkisinin kaybolmaya yüz tuttuğu ve dünyanın neresinde olursa olsun üretim faktörlerinden bilgiye sahip olanların ve bilgiyi kullanmayı becerebilenlerin yararlanmaya başladığı bir ortamda; gerek bireysel gerekse ulusal zenginliğin dinamikleri, girişimci bireylerin düşünsel ve davranışsal aktivitelerinde yatmaktadır. Bu da kişinin kişisel özellikleriyle doğrudan bağlantılıdır. İnsanın bulunduğu her ortamda girişimciden ve dolayısıyla girişimcilikten bahsedebilmenin mümkün olduğu gerçeğinden hareketle, girişimci bireylerin sahip olmaları gereken girişimcilik özelliklerinin çok geniş bir alana yayıldığı söylenebilir (Ören \& Biçkes, 2011, 68-72).

Girişimcilik ile ilgili yapılan çalışmalarda yer alan girişimci kişilik özelliklerinden bazıları; risk alma eğilimi, başarma ihtiyacı, yenilikçilik, kontrol odağı, belirsizlik toleransı ve kendine güvendir.

Risk Alma Eğilimi: Hofstede'ye göre risk; bir olayın meydana gelme olas1lığının oranıyken, belirsizlik ise, bir olasılığa bağlı kalmadan, herhangi bir şeyin olabileceğine yönelik beklentidir ve kaygı yaratır. Eğer belirsizlik risk olarak açılanabiliyorsa bir kaygı kaynağı olmaktan çıkar. Risk kavramı, devam etmekte olan bir olayın sonucunun tam bir belirlilikle ifade edilememesi olarak da tanımlanabilir (Ören \& Biçkes, 201, 73).

Risk alma eğilimi, bir bireyin riskli bir durum ile yüz yüze geldiğinde, risk alma veya riskten sakınma davranışı sergileme eğilimini ifade etmektedir (Gürol \& Atsan, 2006, 30). Risk alma eğilimi, girişimciler için risk, beklenen geri dönüşün maksimum olacağına dair inancı ve rasyonel karar verme vasıtasıyla teşebbüsün gerçekleştirilmesini kapsar. Girişimciler, her zaman geleceği öngören ve risk almaktan korkmayan insanlardır (Yıldız, 2012, 84).

Başarma İhtiyacı: Herhangi bir işin başarılı bir şekilde sonuçlandırılması için temel belirleyicilerden biri olan başarma ihtiyacı, aynı zamanda toplumların ekonomik gelişimlerinin sağlanmasında önemli bir motivasyon aracı olma özelliğine de sahiptir (Ören \& Biçkes, 2011, 73-74).

Geleneksel tanımına göre başarma ihtiyacı, insanı başarı ve mükemmellik için mücadele etmeye sürükleyen itici güçtür. McClelland başarıya yüksek düzeyde ihtiyaç, genç bir insanı başka tür bir pozisyondan elde edilebileceğinden daha fazla başarı tatmini elde etmek amacıyla girişimci bir pozisyon aramaya uygun hale getirmektedir diyerek girişimcilik literatüründeki yapıyı ilk kuran kişi olmuştur (Gürol \& Atsan, 2006, 29). 
McClelland tarafindan ileri sürülen başarı ihtiyacı teorisi, başarı ihtiyacının girişimcilik davranışlarını etkileyen önemli bir faktör olduğunu ileri sürmektedir. Başarma ihtiyac1, insanları girişimciliğe sevk etmek, kontrollü riskleri üstlenmeye yöneltmek, problem çözme becerisini geliştirmek ve amaçların belirlenmesine yardımcı olmak bakımından girişimciliğe katkıda bulunmaktadır (Korkmaz, 2012, 212).

Yenilikçilik: Yeni gelişen anlayış çerçevesinde, bir işletmenin sağlığı ve geleceği için en önemli öğe olarak görülebilecek olan inovasyon, başka bir deyişle yenilikçilik köken olarak 'yeni' anlamına gelen Latince 'nova' sözcüğünden türemiştir. Birçok kez girişimciliğin özünü ve kurumsal girişimciliğin en önemli öğesini oluşturduğu ileri sürülen yenilikçilik, bilginin, örgütsel fonksiyonları yerine getirmek üzere, orijinal, ilintili, benzersiz çözüm ve değer yaratan yeni kaynak, ürün, süreç, hizmet, yönetim tekniği veya teknoloji biçiminde somutlaştırılarak değiştirilmesi, birleştirilmesi ya da sentezlenmesi aracılığıyla ticari değer kazanması sürecidir (Altuntaş \& Dönmez, 2010, 53-54).

Yenilikçilik, girişimcilerin odak noktası ve son derece önemli karakteristik özelliğidir ve yaratıcıllğın ticari versiyonu olarak kabul edilmektedir. Girişimcilerin bakış açısına göre yenilik, pazarlanabilir yenilik anlamına gelmektedir (Y1ldiz, 2012, 84).

Kontrol Odağı: Kontrol odağı, bireylerin kendi hayatlarında meydana gelen olayların altında yatan ana nedenler hakkındaki algisıdır (Okhomina, 2010: 141). İçsel kontrol odağına sahip bireyler, hayatlarında meydana gelen olayları kontrol edebildiklerine, dışsal kontrol odağına sahip bireyler ise hayatlarında meydana gelen olayların şans veya kader gibi dış faktörlerin bir sonucu olduğuna inanmaktadır (Koh, 1996, 14).

Girişimcilerin içsel kontrol odağına sahip olduklarına inanılır ve yeni firsatlar arayan ve yenilikçi bir tutum sergileyen girişimcilerin hayatlarında meydana gelen olayları kontrol edebilme yeteneğine de sahip olmaları beklenir (Gürol \& Atsan, 2006, 29-30).

Belirsizlik Toleransı: Belirsizlik, yetersiz veri nedeniyle yapılandırılamayan bir durum, belirsizlik toleransı ise, belirsiz durumlara karşı pozitif şekilde tepki verebilme yeteneğidir. Eğer bir birey yetersiz veriye razı olur ve belirsizlik durumunda verdiği karara güvenirse, bu tür durumlara karşı tolerans1 yüksek olarak nitelendirilir (Gürol \& Atsan, 2006, 30).

Düşük belirsizlik toleransına sahip kişiler stres ile karşılaşır, zamansız şekilde tepki verir ve belirsiz uyarılardan sakınırlar. Diğer taraftan, belirsizliğe karşı yüksek toleransa sahip kişiler belirsiz durumları/uyarıları arzu edilir, iddialı ve ilgi çekici olarak algılar ve bu tür durumların uyumsuzluğunun karmaşıklığını ne inkâr eder ne de saptırırlar (Okhomina, 2010, 141). 
Genel olarak girişimci yöneticilerin geleneksel yöneticilerden daha iyi şekilde belirsizliği tolere ettiğine inanılır, çünkü girişimciler daha az yapılandırılmış, daha belirsiz ihtimaller kümesi ile karşılaşırlar ve karar ile ilgili nihai sorumluluğu gerçekten üzerlerine alırlar (Gürol \& Atsan, 2006, 30).

Kendine Güven: Kendine güven, bireyin kendi hakkında olumlu ve gerçekçi tutuma sahip olması, bir girişimci için kendine güven ise belirlediği hedefleri başarabileceğine inanmasıdır. Diğer bir ifadeyle, bir girişimci kendi işinde, kendisine saygı duyar ve işi başaracağına dair yeteneklerine güvenirse başarılı olur ve kendine güveni artar (Dündar \& Ağca, 2007, 129).

Özgüven girişimciliğin belirleyici bir faktörü olmaktan ziyade muhtemelen bir sonucudur. Girişimcilik hakkındaki literatürde, girişimcilerin diğer insanlara kıyasla daha yüksek bir düzeyde öz güven sergiledikleri ifade edilmektedir (Gürol \& Atsan, 2006, 30).

\section{3. Üniversite Öğrencilerinin Girişimci Kişilik Özelliklerine}

\section{Yönelik Yapılan Araştırmalar}

Literatürde üniversite öğrencilerinin girişimci kişilik özelliklerine yönelik yapılan araştırmalar mevcuttur. Örneğin Korkmaz (2012) tarafından yapılan Bülent Ecevit Üniversitesi İşletme bölümü öğrencilerinin girişimcilik eğilimlerini belirlemeye yönelik çalışmada, öğrencilerin kendine güvendikleri, yenilikçi oldukları, başarma ihtiyacı duydukları, risk alma eğilimlerinin bulunduğu ancak kontrol odağına sahip olmadıkları ve belirsizliğe karşı tolerans göstermedikleri görülmüştür. Dolayısıyla öğrencilerin girişimcilik eğilimini belirleyen altı girişimci kişilik özelliğinin dördüne sahip olduklarından ötürü girişimciliğe eğilimli oldukları belirlenmiştir.

Ören ve Biçkes (2011), Nevşehir Üniversitesi öğrencileri üzerinde yaptıkları araştırmada, kişilik özelliklerinden başarma ihtiyacı ve risk alma eğilimi ile girişimcilik potansiyeli arasında anlamlı ve pozitif bir ilişki bulmuştur.

İşcan ve Kaygın (2011), Kafkas ve Kırıkkale Üniversitesi İktisadi ve İdari Bilimler Fakültesi son sınıf öğrencilerinin girişimcilik eğilimlerini belirlemeye yönelik çalışmalarında öğrencilerin belirsizliğe karşı tolerans göstermedikleri ancak diğer beş özelliğe sahip oldukları sonucuna ulaşmıştır. Ayrıca erkek öğrencilerin başarma ihtiyacı ve belirsizliğe karşı tolerans gösterme konularında bayan öğrencilerden anlamlı derecede daha başarılı oldukları görülmüştür.

Dündar ve A ğca (2007) tarafindan Afyon Kocatepe Üniversitesi'nde lisans düzeyinde öğrenim gören son sınıf öğrencilerinin girişimcilik özelliklerini belirlemeye yönelik yapılan araştırmada, gelecekte girişimci olma 
eğilimine sahip öğrencilerin olmayanlara göre daha fazla risk alma, kendine güven duyma ve yenilikçilik özelliği sergiledikleri gözlemlenmiş, içsel kontrol odağ 1 , başarı gereksinimi ve belirsizliğe karşı tolerans özellikleri bakımından ise bu iki grup arasında istatistiksel olarak anlamlı farklılıklar çıkmamıştır.

Gürol ve Atsan'ın (2006) yaptıkları çalışmada ise girişimci eğilimi olan öğrencilerde olmayanlara kıyasla belirsizlik toleransı ve kendine güven hariç diğer tüm girişimci kişilik özellikleri yüksek düzeyde bulunmuş, bu öğrencilerin daha yüksek risk alma eğilimi, başarı ihtiyacı, yenilikçilik ve içsel kontrol odağına sahip oldukları sonucuna varılmıştır.

\section{Araştırmanın Metodolojisi}

Araştırmanın ana kitlesini Yalova Üniversitesi Yalova Meslek Yüksekokulunda 2012/2013 bahar döneminde son sinıfta öğrenim gören 910 öğrenci oluşturmaktadır. Anketin son sınıf öğrencilerine uygulanmasının nedeni öğrencilerin kısa sürede iş hayatına atılacak olmalarıdır. $\mathrm{Bu}$ ana kitleyi temsil etmek üzere $\% 95$ güven düzeyi ve $\pm \% 5$ hata marjı için örneklem hacmi 280 öğrenci olarak belirlenmiştir. Anket formları sınıf ortamında 280 öğrenciye elden dağıtılmış, cevaplanan anket formlarının incelenmesi sonucunda 250 anket formunun tam olarak doldurulduğu tespit edilmiştir. Dolayısıyla çalışmanın örneklemi, ana kitledeki her birimin örnekleme eşit olarak girmesine imkan veren tesadüfi örnekleme yöntemiyle ulaşılan 250 öğrenciden oluşmaktadır.

Veri toplama aracı olarak anket formu kullanılmıştır. Anketin birinci bölümünde araştırmaya katılanların cinsiyeti, yaşı, hangi bölümde öğrenci olduğu, ailelerinin gelir ve eğitim durumları ve mezun olduktan sonra girişimcilik kariyeri planlayıp planlamadıklarına ilişkin sorular yer almaktadır. İkinci bölüm ise, girişimciliği etkileyen ve kontrol odağı, başarma ihtiyacı, risk alma eğilimi, belirsizlik toleransı, kendine güven ve yenilikçilik olarak tanımlanan temel psikolojik özellikleri ortaya koyacak ifadelerden oluşmaktadır. Koh tarafindan oluşturulan ölçeği kullanan Dündar ve A ğca (2007) ile doğrudan iletişime geçilerek elde edilen ölçeğin soru önermeleri 5 boyutta beş noktalı likert tipi ölçek sorusu olarak yöneltilmiştir.

\section{Araştırmanın Bulguları}

Araştırmanın verileri SPSS 17 (Statistical Package for the Social Sciences) programında analiz edilmiştir. Kullanılan örneğin geçerlilik ve güvenilirlik analizi sonrası Cronbach Alfa değeri 0,81 olarak bulunmuş olup bu değer ölçeğin güvenilir olduğunu göstermektedir. 
Araştırmaya katılan öğrencilerin cinsiyet, yaş, öğrenim gördükleri bölüm, ailelerinin gelir düzeyi, mezun olduktan sonra girişimci olmayı planlayıp planlamadıkları ve yerleşim yerlerine ilişkin demografik özelliklerin dağılımı Tablo 1'de verilmiştir.

Tablo 1: Araştırmaya Katılan Öğrencilerin Demografik Özelliklerine İlişskin Bulgular

\begin{tabular}{|c|c|c|c|c|c|}
\hline Cinsiyet & Kişi & $\%$ & $\begin{array}{l}\text { Ailenin Gelir } \\
\text { Düzeyi }\end{array}$ & Kişi & $\%$ \\
\hline Kadın & 107 & 42.8 & Üst gelir grubu & 12 & 4.8 \\
\hline \multirow[t]{2}{*}{ Erkek } & 143 & 57.2 & Orta gelir grubu & 196 & 78.4 \\
\hline & & & Alt gelir grubu & 42 & 16.8 \\
\hline Yaş & Kişi & $\%$ & $\begin{array}{c}\text { Mezun olduktan } \\
\text { sonraki iş durumu }\end{array}$ & Kişi & $\%$ \\
\hline $18-23$ & 238 & 95.2 & $\begin{array}{c}\text { Kendi işimi kurmak } \\
\text { isterim }\end{array}$ & 91 & 36.4 \\
\hline $24-29$ & 12 & 4.8 & $\begin{array}{l}\text { Kamu sektöründe } \\
\text { çalışmak isterim }\end{array}$ & 79 & 31.6 \\
\hline Bölüm & Kişi & $\%$ & $\begin{array}{c}\text { Özel sektörde } \\
\text { çalışmak isterim }\end{array}$ & 80 & 32.0 \\
\hline $\begin{array}{l}\text { Sosyal } \\
\text { Bölümler }\end{array}$ & 62 & 24.8 & Yerleşim Yeri & Kişi & $\%$ \\
\hline \multirow[t]{3}{*}{$\begin{array}{c}\text { Sayısal } \\
\text { Bölümler }\end{array}$} & 188 & 75.2 & İl & 141 & 56,4 \\
\hline & & & İlçe & 85 & 34,0 \\
\hline & & & Köy & 24 & 9,6 \\
\hline
\end{tabular}

Çalışmada ölçeklerin güvenilirliği Cronbach alfa istatistiği ile ölçülmüştür. Alpha istatistiği 0 ile 1 arasında değerler almakta ve ölçeğin güvenilirliNİSAN 2014 - EKİM 2014 
ğinin kabul edilebilir olabilmesi için 0,5 ' den büyük olması beklenmektedir. Yapılan güvenilirlik analizi sonucunda öğrencilerin girişimcilik eğilimlerine yönelik altı farklı boyutlarına ait Cronbach alfa istatistiği 0.510- 0,680 arasında bulunmuştur. ve bu sonuçlar söz konusu bu alt boyutların kabul edilebilir bir güvenilirliğe sahip olduğunu göstermektedir. Tablo 2'de öğrencilerin girişimcilik eğilimini ölçerken dikkate alınan alt boyutlar, bu alt boyutları ölçmek için kullanılan soru sayısı ve alt boyutların güvenilirliği yer almaktadır.

Tablo 2: Girişimcilik Eğiliminin Alt Boyutları ve Güvenilirlik

\begin{tabular}{|l|c|c|}
\hline \multicolumn{1}{|c|}{ Alt Boyutlar } & Soru Sayısı & Güvenilirlik \\
\hline Kontrol Odağı & 3 & 0,511 \\
\hline Başarma ihtiyacı & 5 & 0,655 \\
\hline Risk alma Eğilimi & 5 & 0,523 \\
\hline Belirsizlik toleransı & 5 & 0,605 \\
\hline Kendine güven & 4 & 0,510 \\
\hline Yenilikçilik & 4 & 0,580 \\
\hline
\end{tabular}

Çalışmada araştırmaya katılan öğrencilerin demografik özellikleri ile girişimci kişilik özelliklerinin farklı olup olmadığını test etmek amacıyla parametrik olmayan testlerden yararlanılmıştır.

Çalışmada araştırmaya katılan öğrencilerin demografik özelliklerinden cinsiyet ve yaşa göre girişimci kişilik özelliklerinin farklılık gösterip göstermediğini incelemek amacıyla, Mann- Whitney U testi, öğrencilerin ailelerinin ekonomik durumlarına göre ve yaşadıkları yerleşim yerlerine göre girişimci kişilik özelliklerinin farklılık gösterip göstermediğini ortaya koymak amacıyla ise Kruskal-Wallis H testi yapılmıştır.

Araştırmaya katılan öğrencilerin cinsiyetleri ile girişimci kişilik özelliklerine bakış açıları üzerinde etkisi olup olmadığını belirlemek için yapılan Mann-Whitney U testi sonuçları Tablo 3'de verilmiştir. Hipotezler aşağıdaki gibidir:

$\mathrm{H}_{0}$ : Cinsiyetin, kontrol odağı, başarma ihtiyacı, risk alma eğilimi, belirsizlik toleransı, kendine güven ve yenilikçilik boyutlarına bakış açıları üzerinde bir etkisi yoktur. 
$\mathrm{H}_{1}$ : Cinsiyetin, kontrol odağı, başarma ihtiyacı, risk alma eğilimi, belirsizlik toleransı, kendine güven ve yenilikçilik boyutlarına bakış açıları üzerinde bir etkisi vardır.

Tablo 3: Öğrencilerin cinsiyetleri ile Girişimcilik Eğilimleri Arasındaki Farklııklarının Mann-Whitney U Testi Sonuçları

\begin{tabular}{|c|c|c|c|c|c|}
\hline & Cinsiyet & $\mathbf{N}$ & $\begin{array}{l}\text { Sıra değer } \\
\text { ortalama }\end{array}$ & $\begin{array}{c}\text { Mann-Whitney } \\
\text { U istatistiği }\end{array}$ & $\mathbf{P}$ \\
\hline Kontrol Odağı & $\begin{array}{l}\text { Erkek } \\
\text { Kadın }\end{array}$ & $\begin{array}{l}143 \\
107\end{array}$ & $\begin{array}{l}120,22 \\
132,56\end{array}$ & 6895,000 & ,178 \\
\hline Başarma İhtiyacı & $\begin{array}{l}\text { Erkek } \\
\text { Kadın }\end{array}$ & $\begin{array}{l}143 \\
107\end{array}$ & $\begin{array}{l}116,74 \\
137,20\end{array}$ & 6398,500 & ,026 \\
\hline Risk Alma Eğilimi & $\begin{array}{l}\text { Erkek } \\
\text { Kadın }\end{array}$ & $\begin{array}{l}143 \\
107\end{array}$ & $\begin{array}{l}126,70 \\
123,90\end{array}$ & 7479,500 & ,762 \\
\hline Belirsizlik Toleransı & $\begin{array}{l}\text { Erkek } \\
\text { Kadın }\end{array}$ & $\begin{array}{l}143 \\
107\end{array}$ & $\begin{array}{l}120,41 \\
132,30\end{array}$ & 6922,500 & , 196 \\
\hline Kendine güven & $\begin{array}{l}\text { Erkek } \\
\text { Kadın }\end{array}$ & $\begin{array}{l}143 \\
107\end{array}$ & $\begin{array}{l}124,12 \\
127,34\end{array}$ & 7453,500 & ,726 \\
\hline Yenilikçilik & $\begin{array}{l}\text { Erkek } \\
\text { Kadın }\end{array}$ & $\begin{array}{l}143 \\
107\end{array}$ & $\begin{array}{l}125,21 \\
125,89\end{array}$ & 7609,000 & ,941 \\
\hline
\end{tabular}

Yapılan Mann-Whitney-U testi sonucunda (0.05 anlamlılık seviyesinde) öğrencilerin cinsiyetinin, başarma ihtiyacı boyutu üzerinde anlamlı bir etkisinin olduğu, kontrol odağı, risk alma eğilimi, belirsizlik tolerans1, kendine güven ve yenilikçilik boyutları üzerinde ise anlamlı bir etkisinin olmadığ lirlenmiştir.

Araştırmaya katılan öğrencilerin yaşları ile girişimci kişilik özelliklerine bakış açıları üzerinde fark olup olmadığını belirlemek için yapılan Mann Whitney U testi sonuçları Tablo 4'de verilmiştir. Hipotezler aşağıdaki gibidir:

$\mathrm{H}_{0}$ : Yaşın, kontrol odağı, başarma ihtiyacı, risk alma eğilimi, belirsizlik toleransı, kendine güven ve yenilikçilik boyutlarına bakış açıları üzerinde bir etkisi yoktur.

$\mathrm{H}_{1}$ : Yaşın, kontrol odağ 1 , başarma ihtiyac1, risk alma eğilimi, belirsizlik toleransı, kendine güven ve yenilikçilik boyutlarına bakış açıları üzerinde bir etkisi vardır. 
118 • YALOVA SOSYAL BİLİMLER DERGİSİ

Tablo 4: Öğrencilerin Yaş Değişkeni ile Girişimcilik Eğilimleri Arasındaki Farklılıklarının Mann Whitney U testi sonuçları

\begin{tabular}{|c|c|c|c|c|c|}
\hline & Yaş & $\mathbf{N}$ & $\begin{array}{c}\text { Sira değer } \\
\text { ortalama }\end{array}$ & $\begin{array}{c}\text { Mann-Whitney } \\
\text { U istatistiği }\end{array}$ & $\mathbf{P}$ \\
\hline Kontrol Odağı & $\begin{array}{l}18-23 \\
24-29\end{array}$ & $\begin{array}{c}238 \\
12\end{array}$ & $\begin{array}{c}\mathbf{1 2 7}, \mathbf{5 2} \\
85,42\end{array}$ & 947,000 & ,004 \\
\hline Başarma İhtiyacı & $\begin{array}{l}18-23 \\
24-29\end{array}$ & $\begin{array}{c}238 \\
12\end{array}$ & $\begin{array}{c}127,10 \\
93,75\end{array}$ & 1047,000 &, 118 \\
\hline Risk Alma Eğilimi & $\begin{array}{l}18-23 \\
24-29\end{array}$ & $\begin{array}{c}238 \\
12\end{array}$ & $\begin{array}{l}126,72 \\
101,33\end{array}$ & 1138,000 & ,234 \\
\hline Belirsizlik Toleransı & $\begin{array}{l}18-23 \\
24-29\end{array}$ & $\begin{array}{c}238 \\
12\end{array}$ & $\begin{array}{l}126,57 \\
104,29\end{array}$ & 1173,500 & ,296 \\
\hline Kendine güven & $\begin{array}{l}18-23 \\
24-29\end{array}$ & $\begin{array}{c}238 \\
12\end{array}$ & $\begin{array}{l}126,70 \\
101,75\end{array}$ & 1143,000 & ,241 \\
\hline Yenilikçilik & $\begin{array}{l}18-23 \\
24-29\end{array}$ & $\begin{array}{c}238 \\
12\end{array}$ & $\begin{array}{c}127,38 \\
88,13\end{array}$ & 979,500 &, 065 \\
\hline
\end{tabular}

Yapılan Mann Whitney U testi sonucunda öğrencilerin yaşlarının sadece kontrol odağı boyutuna bakış açıları üzerinde anlamlı bir etkisinin olduğu, başarma ihtiyac1, risk alma eğilimi, belirsizlik toleransı, kendine güven ve yenilikçilik boyutları üzerinde ise anlamlı bir etkisinin olmadığı belirlenmiştir.

Araştırmaya katılan öğrencilerin ailelerinin ekonomik durumları ile girişimcilik eğilimleri arasında bir fark olup olmadığını ortaya koymak amacıyla Kruskal Wallis H testi yapılmıştır. Elde edilen test sonuçları tablo 5'de verilmiştir. Hipotezler aşağıdaki gibidir:

$\mathrm{H}_{0}$ : Öğrencilerin ailelerinin ekonomik durumları ile kontrol odağı, başarma ihtiyac1, risk alma eğilimi, belirsizlik toleransı, kendine güven ve yenilikçilik boyutlarına bakış açıları arasında bir fark yoktur.

$\mathrm{H}_{1}$ : Öğrencilerin ailelerinin ekonomik durumları ile kontrol odağı, başarma ihtiyacı, risk alma eğilimi, belirsizlik toleransı, kendine güven ve yenilikçilik boyutlarına bakış açıları arasında bir fark vardır. 
Tablo 5: Öğrencilerin Ailelerinin Ekonomik Durumları ile Girişimcilik Eğilimleri Arasındaki Farklılıklarının Kruskal Wallis H Testi Sonuçları

\begin{tabular}{|c|c|c|c|c|c|}
\hline & Gelir Grubu & $\mathbf{N}$ & $\begin{array}{c}\text { Sıra } \\
\text { değer } \\
\text { ortalama }\end{array}$ & $\mathbf{X}^{2}$ & $\mathbf{P}$ \\
\hline Kontrol Odağı & $\begin{array}{l}\text { Üst Gelir Grubu } \\
\text { Orta Gelir Grubu } \\
\text { Alt Gelir Grubu }\end{array}$ & $\begin{array}{r}12 \\
196 \\
42\end{array}$ & $\begin{array}{l}140,79 \\
124,71 \\
124,83\end{array}$ & 0,573 &, 751 \\
\hline Başarma İhtiyacı & $\begin{array}{l}\text { Üst Gelir Grubu } \\
\text { Orta Gelir Grubu } \\
\text { Alt Gelir Grubu }\end{array}$ & $\begin{array}{r}12 \\
196 \\
42\end{array}$ & $\begin{array}{l}130,42 \\
125,42 \\
124,49\end{array}$ & 0,064 & ,968 \\
\hline Risk Alma Eğilimi & $\begin{array}{l}\text { Üst Gelir Grubu } \\
\text { Orta Gelir Grubu } \\
\text { Alt Gelir Grubu }\end{array}$ & $\begin{array}{r}12 \\
196 \\
42\end{array}$ & $\begin{array}{l}133,71 \\
122,49 \\
137,19\end{array}$ & 1,604 & ,448 \\
\hline $\begin{array}{l}\text { Belirsizlik } \\
\text { Toleransı }\end{array}$ & $\begin{array}{l}\text { Üst Gelir Grubu } \\
\text { Orta Gelir Grubu } \\
\text { Alt Gelir Grubu }\end{array}$ & $\begin{array}{r}12 \\
196 \\
42\end{array}$ & $\begin{array}{l}122,50 \\
122,79 \\
139,01\end{array}$ & 1,776 & ,411 \\
\hline Kendine güven & $\begin{array}{l}\text { Üst Gelir Grubu } \\
\text { Orta Gelir Grubu } \\
\text { Alt Gelir Grubu }\end{array}$ & $\begin{array}{r}12 \\
196 \\
42\end{array}$ & $\begin{array}{l}\mathbf{1 7 9 , 1 7} \\
121,25 \\
129,99\end{array}$ & 7,525 & ,023 \\
\hline Yenilikçilik & $\begin{array}{l}\text { Üst Gelir Grubu } \\
\text { Orta Gelir Grubu } \\
\text { Alt Gelir Grubu }\end{array}$ & $\begin{array}{r}12 \\
196 \\
42\end{array}$ & $\begin{array}{l}153,04 \\
124,87 \\
120,56\end{array}$ & 1,978 & ,372 \\
\hline
\end{tabular}

Kruskal Wallis $\mathrm{H}$ testi sonucuna göre öğrencilerin ailelerinin ekonomik durumları ile kendine güven boyutu bakış açısı üzerinde anlamlı bir fark olduğu belirlenirken kontrol odağı, başarma ihtiyacı, risk alma eğilimi, belirsizlik toleransı ve yenilikçilik boyutlarına bakış açıları üzerinde ise anlamlı bir farkın olmadığı görülmektedir.

Araştırmaya katılan öğrencilerin yerleşim yerleri ile girişimcilik eğilimleri arasında bir fark olup olmadığını ortaya koymak amacıyla Kruskal Wallis $\mathrm{H}$ testi yapılmıştır. Elde edilen test sonuçları tablo 6'da verilmiştir. Hipotezler aşağıdaki gibidir:

$\mathrm{H}_{0}$ : Öğrencilerin yerleşim yerleri ile kontrol odağ 1 , başarma ihtiyac1, risk alma eğilimi, belirsizlik toleransı, kendine güven ve yenilikçilik boyutlarına bakış açıları arasında bir fark yoktur. 
$120 \bullet$ YALOVA SOSYAL BİLİMLER DERGİSİ

$\mathrm{H}_{1}$ : Öğrencilerin yerleşim yerleri ile kontrol odağ 1 , başarma ihtiyacı, risk alma eğilimi, belirsizlik toleransı, kendine güven ve yenilikçilik boyutlarına bakış açıları arasında bir fark vardır.

Tablo 6. Öğrencilerin Yerleşim Yeri ile Girişimcilik Eğilimleri Arasındaki Farklılıklarının Kruskal Wallis H Testi Sonuçları

\begin{tabular}{|c|c|c|c|c|c|}
\hline & Yerleşim Yeri & $\mathbf{N}$ & $\begin{array}{c}\text { Sira değer } \\
\text { ortalama }\end{array}$ & $\mathbf{X}^{2}$ & $\mathbf{P}$ \\
\hline Kontrol Odağı & $\begin{array}{c}\text { İl } \\
\text { İlçe } \\
\text { Köy }\end{array}$ & $\begin{array}{c}141 \\
85 \\
24\end{array}$ & $\begin{array}{l}130,73 \\
121,71 \\
108,17\end{array}$ & 2,389 &, 303 \\
\hline Başarma İhtiyacı & $\begin{array}{c}\text { İl } \\
\text { İlçe } \\
\text { Köy }\end{array}$ & $\begin{array}{c}141 \\
85 \\
24\end{array}$ & $\begin{array}{l}125,59 \\
126,29 \\
122,19\end{array}$ & 0,061 & ,970 \\
\hline Risk Alma Eğilimi & $\begin{array}{c}\text { İl } \\
\text { İlçe } \\
\text { Köy }\end{array}$ & $\begin{array}{l}141 \\
85 \\
24\end{array}$ & $\begin{array}{l}125,30 \\
126,04 \\
124,77\end{array}$ & 0,008 & ,996 \\
\hline Belirsizlik Toleransı & $\begin{array}{c}\text { İl } \\
\text { İlçe } \\
\text { Köy }\end{array}$ & $\begin{array}{c}141 \\
85 \\
24\end{array}$ & $\begin{array}{l}126,18 \\
129,33 \\
107,96\end{array}$ & 1,676 & ,433 \\
\hline Kendine Güven & $\begin{array}{c}\text { İl } \\
\text { İlçe } \\
\text { Köy }\end{array}$ & $\begin{array}{c}141 \\
85 \\
24\end{array}$ & $\begin{array}{l}135,82 \\
109,84 \\
120,31\end{array}$ & 7,055 & ,029 \\
\hline Yenilikçilik & $\begin{array}{l}\text { İl } \\
\text { İlçe } \\
\text { Köy }\end{array}$ & $\begin{array}{c}141 \\
85 \\
24\end{array}$ & $\begin{array}{l}131,64 \\
118,83 \\
113,04\end{array}$ & 2,486 & 289 \\
\hline
\end{tabular}

Kruskal Wallis H testi sonucuna göre öğrencilerin yerleşim yerleri ile kendine güven boyutu bakış açısı üzerinde anlamlı bir fark olduğu belirlenirken kontrol odağı, başarma ihtiyacı, risk alma eğilimi, belirsizlik toleransı ve yenilikçilik boyutlarına bakış açıları üzerinde ise anlamlı bir farkın olmadığı görülmektedir.

\section{Sonuç ve Öneriler}

Yalova Üniversitesi Yalova Meslek Yüksekokulunda öğrenim gören son sınıf öğrencilerine yönelik olarak yapılan çalışmada öğrencileri girişimcilik 
eğilimini belirleyen psikolojik, demografik ve aile faktörleri araştırılmıştır. Çalışmada ayrıca araştırmaya katılan öğrencilerin cinsiyet ve yaşlarına göre girişimcilik eğilimlerinin farklılık gösterip göstermediğini belirleyebilmek amaciyla yapılan Mann Whitney U testi sonucunda cinsiyetin başarma ihtiyac1 boyutu üzerinde anlamlı bir etkisinin olduğu, kontrol odağı, risk alma eğilimi, belirsizlik toleransı, kendine güven ve yenilikçilik boyutları üzerinde ise anlamlı bir etkisinin olmadığı belirlenmiştir. Yaşın ise kontrol odağı boyutuna bakış açıları üzerinde anlamlı bir etkisinin olduğu, başarma ihtiyacı, risk alma eğilimi, belirsizlik toleransı, kendine güven ve yenilikçilik boyutları üzerinde ise anlamlı bir etkisinin olmadığ

Öğrencilerin ailelerinin ekonomik durumları ve yerleşim yerleri ile girişimcilik eğilimleri arasındaki ilişkiyi incelemek amacıyla yapılan Kruskal Wallis $\mathrm{H}$ testi sonucuna göre ailelerin ekonomik durumları ile kendine güven boyutuna bakış açıları arasında anlamlı bir fark olduğu, yerleşim yeri ile yine kendine güven boyutuna bakış açıları arasında anlamlı bir fark olduğu tespit edilmiştir.

Girişimciliğin gün geçtikçe artan önemi ve kişilik özelliklerinin girişimciliğe olan etkisi dikkate alındığında girişimci kişilik özelliklerinin belirlenmesi ve bu özelliklerin gelecekte girişimci olmayı planlayanlar ile planlamayanlar arasındaki farkların ortaya konması bakımından literatüre katkı sağlamaktadır. Özellikle üniversite öğrencileri için, girişimciliği önemli bir kariyer firsatı olarak değerlendirmek mümkündür. Dolayısıyla girişimciliğin teşvik edilmesi amacıyla öğrencilerin gerek üniversiteler gerekse devlet tarafindan desteklenmesi gerekmektedir. 


\section{KAYNAKÇA}

Altuntaş, G. ve Dönmez, D. (2010). Girişimcilik Yönelimi ve Örgütsel Performans İlişkisi: Çanakkale Bölgesinde Faaliyet Gösteren Otel İşletmelerinde Bir Araştırma. İstanbul Üniversitesi İşletme Fakültesi Dergisi, 39(1): 50-74.

Arasteh, H., Enayati, T., Zameni, F. ve Khademloo, A. (2012). Entrepreneurial Personality Characteristics of University Students: A Case Study. Social and Behavioral Sciences, 46, 5736-5740.

Dündar, S. ve Ağca, V. (2007). Afyon Kocatepe Üniversitesi Lisans Öğrencilerinin Girişimcilik Özelliklerinin İncelenmesine İlişkin Ampirik Bir Çalışma. Hacettepe Üniversitesi İktisadi ve İdari Bilimler Fakültesi Dergisi, 25(1): 121-142.

Fairlie, R. W. ve Holleran, W. (2012). Entrepreneurship Training, Risk Aversion and Other Personality Traits: Evidence from A Random Experiment. Journal of Economic Psychology, 33: 366-378.

Gürol, Y. ve Atsan, N. (2006). Entrepreneurial Characteristics Amongst University Students Some Insides for Entrepreneurship Education and Training in Turkey. Education + Training, 48(1): $25-38$.

İşcan, Ö. F. ve Kaygın, E. (2007). Üniversite Öğrencilerinin Girişimcilik Eğilimlerini Belirlemeye Yönelik Bir Araştırma. Atatürk Üniversitesi Sosyal Bilimler Enstitüsü Dergisi, 15(2): 443-462.

Koh, H. C. (1996). Testing Hypotheses of Entrepreneurial Characteristics A Study of Hong Kong MBA Students. Journal of Managerial Psychology, 11(3): 12-25.

Korkmaz, O. (2012). Üniversite Öğrencilerinin Girişimcilik Eğilimlerini Belirlemeye Yönelik Bir Araştırma: Bülent Ecevit Üniversitesi Örneği. Afyon Kocatepe Üniversitesi İktisadi ve İdari Bilimler Fakültesi Dergisi, 14:2, 2012, 209-226.

Okhomina, D. A. (2010). The Relationship Between Personality Traits and Entrepreneurial Behavior And The Moderating Role of A Supportive Environment. International Journal of Business and Economics Perspectives, 5(1): 139-154.

Ören, K. ve Biçkes, M. (2011). Kişilik Özelliklerinin Girişimcilik Potansiyeli Üzerindeki Etkileri (Nevşehir'deki Yüksek Öğrenim Öğrencileri Üzerinde Yapılan Bir Araştırma). Süleyman Demirel Üniversitesi İktisadi ve İdari Bilimler Fakültesi Dergisi, 16(3): 67-86.

Yild1z, S. (2011). The Relationship Between Entrepreneurship Traits and Personality Type: A Research in Turkey. International Journal of Academic Research, 4(3): 83-88.

Zarafshani, K. ve Rajabi, S. (2011). Effects of Personality Traits on Entrepreneurial Intentions: An Empirical Study in Iran. International Journal of Management, 28(3): 630-641. 